\title{
Analysis on the Use of Callaghanese Naturalism in his Such Is My Beloved
}

\author{
Yang Yang 1 ,a \\ ${ }^{1}$ Building A6 Room 408, No. 8 Software Park Road, Ganjingzi District, Dalian City, Liaoning \\ Province, P. R. China \\ Dalian Neusoft University of Information \\ akathleenyoung@163.com
}

Keywords: Callaghanese naturalism, urban realism, moralistic concern, and spiritual perfection.

\begin{abstract}
Morley Callaghan is a distinguished Canadian writer who has generally been accepted as the Father of modern Canadian fiction in the 20th Century. Greatly influenced by Ernest Hemingway and Jacque Maritain, he further developed his own style-known as Callaghanese fictions. This paper is to make an analysis on the use of his Callaghanese naturalism in his masterpiece Such Is My Beloved in terms of setting, theme, characterization and so on.
\end{abstract}

\section{Introduction of Morley Callaghan}

Morley Callaghan (1903-1990) is a Canadian novelist who has generally been accepted as the Father of modern Canadian fiction. He was the first Canadian author to rank among the modern greats, as well as was the first one who focused on the topic of realistic fictions in Canadian English literature in the $20^{\text {th }}$ Century.

Callaghan got acquainted with Ernest Hemingway when they both worked at the Toronto Star in the 1920s. Greatly influenced by Hemingway, Morley Callaghan inherited his American way in literary creation and then he further developed the American style naturalism in his own way, which is known as Callaghanese naturalism. In his literary creation, he showed more interest in religion, morality, criminal psychology and so on.

Meanwhile, he also absorbed the philosophy of Jacque Maritain (1882-1973), a French Catholic philosopher who was the representative of neo-Thomism. Maritain's moral philosophy played a critical role in Callaghan's expression of the achievement of moral and spiritual perfection in his vivid character portrait. Owing to his religious belief and philosophical influence from Maritain, Callaghan often tried to probe human nature, human freedom, and human moral and spiritual perfection in his works.

\section{The Main Plot of Such Is My Beloved}

Such Is My Beloved (1934), widely considered to be Morley Callaghan's finest novel, is one of the triptych novels followed by They Shall Inherit the Earth (1935) and More Joy in Heaven (1937). It was actually one of the triads based on a story happened in Paris told by Maritain, who had inspired Callaghan with his philosophy influence in terms of writing.

As one of the great novels of the 1930s, it describes a tragic story of two down-and-out prostitutes Ronnie Olsen and Midge Bourassa and the young priest Father Stephen Dowling who aspires to redeem their lives. The story begins with the description of the central protagonist-Father Dowling, "the most eager young priest at the Cathedral":

From the time of his ordination he had approached every bit of parish work with enthusiasm and preached with such passion... [1]

Father Dowling's eagerness at parish work continued until he met two girls-Ronnie and Midge - two prostitutes coming to live in the same parish where Father Dowling worked. Out of enthusiasm at work, Father Dowling became very sympathetic for the girls because of their awkward state of life. 
At that moment he was feeling more love for the two girls than he had ever felt before because their lives were so wretched, because their clothes were so shabby, and even when they bought new things they were in poor taste. [1]

Father Dowling not only provided financial aid occasionally to help them out, but also tried to seek rightful jobs for them. However, the salvation of these two girls was in vain, for it was Father Dowling's own wishful thinking. Either of the two girls was reluctant to abandon the current state of life. Out of their laziness as well as under the pressure of declining social and economic conditions, the two girls were no longer willing to make a living in an ordinary way. Besides, Father Dowling's attempt to rescue them could not be understood by people around. He was alone to face personal moral dilemmas.

In the story, Father Dowling was actually playing the role as a compassionate portrait of innocence and idealism, and an emphatic condemnation of a society where the lines between good and evil are essentially blurred. In the end, his eagerness led to a series of adverse consequences: he got a psychic breakdown into madness, and the girls were arrested by the police.

\section{Writing Features of Morley Callaghan's Such Is My Beloved}

According to its definition, naturalism is a more deliberate kind of realism in novels, stories, and plays, which often involves a view of human beings as passive victims of natural forces and social environment. [2] However, naturalism is sometimes claimed to give an even more accurate depiction of life than realism. Naturalistic authors selected particular parts of reality: misery, corruption, vice, disease, poverty, prostitution, racism, and violence. They were criticized for being pessimistic and for concentrating excessively on the darker aspects of life.

Heavily influenced by Hemingway and his American style naturalism, Callaghan inherited and further developed his fictions into a unique style of its own, which is known as "Callaghanese fiction". Callaghan's naturalism is a kind of urban realism. He frequently depicts a hero who is at the mercy of larger social forces, which represent a cruel, overmastering fate. And the forces of characters often seem just as implacable as those of society. [3] His masterpiece Such Is My Beloved is not an exception, whose naturalistic setting, theme, and characterization are to be analyzed as follows:

3.1 Callaghanese Naturalistic Setting. Different from Hemingway's stories, Callaghan's naturalistic settings are always the kind of unban ones, although the traditional naturalistic literature often cast stories in a Mother Nature environment, which was filled with dangerous animals, severe climate, and some other vital natural forces to conquer, etc. Callaghan likes to cast his stories in modern cities, partly because he focused on small and moral quandaries arising in early $20^{\text {th }}$ century, but universal to all times and societies in which economic injustice existed and personal conscience confronted societal hypocrisy.

The story of Such Is My Beloved was set in a parish of the city Montreal around the years when the First World War had just come to an end and followed by the Great Depression. The story gives a vivid description about how the First World War had made a great impact upon people's lifestyle and ideology: Some people became less certain about the changing world and more cynical about accepted standards of honesty and morality. The idea of "seize the day" or "enjoy the present" was pervasive. Affected by ill ideas, Ronnie and Midge, the two main characters in the story, were no longer innocent girls and began to change their attitudes towards sex. Instead of thinking of sex as something obscene or wrong, the two girls took up prostitution as their jobs. Ronnie, "the serious, abrupt tall girl" and Midge, "the little one with coaxing mouth and solemn eyes", would be on the streets night after night... Such a corrupted society was depicted as a spiritual wasteland: "These girls have prostituted their bodies. All around us there are all kinds of people prostituting their souls and their principles for money. I know people in this city who prostitute our faith for the sake of expediency." [1]

On the other hand, there was not only a decline in moral standard, but also a depression in economy - the Great Depression broke in 1929 — which life was made more unfavorable and harsher to survive or conquer. Another reason for why Ronnie and Midge prostituted their bodies 
partly lies in their lower-economic-class identification. Their lives were so wretched, and they found it more difficult to find a lawful job when the unemployment rate roared during the Great Depression. They were actually the victims of the time while war, poverty and social uprising were on big canvases. Such a social environment not only made Ronnie and Midge feel unconquerable, but also hampered Father Dowling - a Christian from helping them out.

3.2 Callaghanese Naturalistic Theme. Speaking of the naturalistic theme of Such Is My Beloved, taboo and determinism are the two typical components of Callaghan's moralistic concern. In the story, determinism gives expression to several aspects: the society with economic depression and mass unemployment seems unconquerable for the ill-educated poor Ronnie and Midge to find a decent job to eke out a living; contemptuous attitudes from the upper class towards the lower class is difficult for Father Dowling to persuade other noble parishioners like Mr. Robison to offer any help; and Ronnie and Midge's compromise for morality is not divorced from their weakness of personality, such as laziness, feeble-mind.

Taboo is another embodiment of the novel's theme: it is a taboo for a priest to contact with prostitutes; it is also a taboo for girls to violate morality by taking up an obscene job like prostitution. Thematically, the story examines the conflicts arising between the individual and ideology, personal desire and public need, individual lust and a society that seeks to influence, to create obstacles to the fulfillment of that lust.

3.3 Callaghanese Naturalistic Characters. Father Dowling, Ronnie, Midge, Father Anglin, Mr. Robison and his wife are the representative characters in the story. Like most naturalistic literary works, each character inherits compulsive instincts - especially the drive to accumulate possessions, and sexuality - and is then subject to "the social and economic forces in the family, the class, and the milieu into which that person is born". [4]

In terms of characterization, Callaghan often deals with the struggle of flawed but noble individuals to make it in a hostile or indifferent world. Father Dowling was just such kind of character. He was young, determined and confident in God. He kept showing so much eagerness at his work and warm-hearted to help so many parishioners who were in physical and spiritual torture of life. He could understand the dilemma of the lower class very well and he even sacrificed his sanity to save Ronnie and Midge. However, he just offered his help out of conscience and religious belief without thinking about other people's standpoints.

Ronnie and Midge were two ill-educated lower-class girls, who took up prostitution out of living pressure. Before coming to Montreal, they wanted to find an honorable job and led a tranquil life, but they could never accomplish forever in reality. Out of laziness and feeble-minded personality, they finally broke their words although they had promised Father Dowling to give up prostitution. Later, Ronnie even got disgusted with Father Dowling and his help because she didn't want him to intrude upon their routine life; while Midge assumed an ambiguous attitude because she felt contradictory between her ideal life and present situation. The compromise of morality roots in the weakness of their personalities.

Father Anglin, Mr. Robison and his wife should be the representative of social law and order, but they did nothing to prevent prostitution. They were famous for charitable work, but no one want to offer any help to the two girls. For fearing incurring trouble and rumor, they all felt it ridiculous to help prostitutes. Their indifference led in Father Dowling's exiling and the two girls' arrest by the police. Their behaviors had fully exposed their selfishness, hypocrisy, indifference, which determined Father Dowling's mental breakdown.

\section{Conclusion}

Such Is My Beloved is a tragedy. By reflecting his naturalistic techniques, Callaghan attributes the root causes to the following three points:

First, the naturalistic social environment is one of the most important factors that accounts for the tragedy. World War I and the Great Depression had brought incredible damage to the whole society, the whole mortal, and the whole civilization.

Second, the story is also a moral tale with a tragic theme. Determinism and taboo are identified 
as the key naturalistic theme: the conflicts arising between the individual and ideology, personal desire and public need, individual lust and a society that seeks to influence, to create obstacles to the fulfillment of that lust.

Finally, the weakness of human nature of all the naturalistic characters of the story is also the fatal factors leading to the tragedy. For example, the two girls' insensibility in the 1930s shows a compromise of morality towards sex. Besides, Callaghan's moralistic concern also lies in the conflict between class consciousness and newly arisen ideology. The upper class's way of thinking or attitudes towards the lower class has exposed their nature of hypocrisy and indifference.

To sum up, Callaghan invites the typical techniques of American naturalism with Canadian local color, which is apparent in Such Is My Beloved, a moral tale that reflects his pursuit of moral and spiritual perfection of human beings. There is no doubt that reading one Callaghan story every night before going to bed will make you a better person.

\section{References}

[1] Morley Callaghan, Such Is My Beloved.pp. 7, pp. 67, 1934.

[2] Chris Baldick, Oxford Concise Dictionary of Literary Terms. pp. 146, 2000.

[3] David Mikics, A Handbook of Literary Terms, pp. 200, 2007.

[4] Meyer Howard Abrams, A Glossary of Literary Terms 10 ${ }^{\text {th }}$ ed., pp. 335, 2014. 